\title{
In-Between Surveillance and Spatial Protest the Production of Space of the 'Mixed City' of Lod"
}

\section{Haim Yac obi1}

\begin{abstract}
This paper analyses the historical process during which the Israeli territory, including previously Palestinian cities, has been profoundly Judaized. More specifically, Based on Henri Lefebvre's conceptualization of the production of space, the paper focuses on the case of the 'mixed city' of Lod, accentuating the informal mechanisms of housing and infrastructure supply, the "strategic reversibility" of power relations and the struggle for identity evident in the Palestinian community's protest in this city. Theoretically, the paper highlights the ways in which social conflict is expressed through analyzing the conceived space, the perceived space and the lived space. By doing so, it reconceptualizes the act of urban resistance, and to stress the role of spatial protest as an alternative pattern of opposition vis a vis the surveillance mechanisms implemented in the city.
\end{abstract}

\section{Introduction}

'Mixed cities' is a widely used term in Israel, describing an urban situation in which Jewish and Arab communities occupy the same urban jurisdiction. However, a critical examination questions this terminology that brings to mind integration and mutual membership of society, while reality is controversial. Similar to other cases of ethnic nationalism, a clear spatial and mental division exists between Arabs and Jews in Israel, and hence the occurrence of 'mixed' spaces is both exceptional and involuntary. Rather, it has resulted from a historical process during which the Israeli territory, including previously Palestinian cities, has been profoundly Judaized. Hence, as this paper suggest, these ethnically mixed territories are subject of constant surveillence and control.

\footnotetext{
* I am indebted to the PARC (Palestinian-American Research Center), to the Herzog Center for Middle East Studies and Diplomacy for their research grants. I would also like to thank the Israel Science Foundation for its generous financial support of the project entitled: 'Israel's Land Regime, 1948-1998', headed by Prof. Oren Yiftachel and Dr. Sandi Kedar. Some parts of this article were published in: Yacobi, H., (2003). "Everyday Life in Lod: On Power,Identity, and Spatial Protest in a Mixed City". Jaama(10). p.p.: 69-110 (Hebrew).

${ }^{1}$ Department of Politics and Government, Ben Gu rion University, Israel Department of Architecture Bezalel Academy, Israel. mailto:yappan@zahav.net.il
} 
Based on Henri Lefebvre's conceptualization of the production of space, in this paper I aim to focus on one case - the 'mixed city' of Lod. Through this theoretical perspective I will present the findings of a fieldwork taken in the city from 1999 to 2003. These findings accentuate the informal mechanisms of housing and infrastructure supply, the "strategic reversibility" of power relations (Foucault in Gordon, 1991:5) and the struggle for identity evident in the Palestinian community's protest in this city. In this paper I will highlight the ways in which social conflict is expressed through analyzing the conceived space, the perceived space and the lived space. By doing so, I aim to rephrase the act of urban resistance, and to stress the role of spatial protest as an alternative pattern of opposition vis a vis the surveillance mechanisms implemented in the city. Spatial protest is characterized by autonomous initiatives reflecting personal and social needs that challenge the interests of those in power. These acts are based on existing communal networks and despite their randomness they identify the limits of the state's control over those that contradict its hegemony. However, this form of protest, I will suggest, does not necessarily reflect conscious resistance, but rather produces it and thus has a subversive potential.

This paper is structured as follows: I will start with describing the socio-political and demographic processes that have shaped the percived space in Lod. In the following section I will present the conceived space, namely the role of planners and planning in transforming the form and meaning of the Palestinian city of Lydd into the 'mixed city'of Lod. Finally, I will explore the lived space, i.e. the effect of such processes on the symbolc meaning of the city to its Palestinian inhabitants.

\section{Urban Panopticism}

In this section I aim to describe the perceived space, i.e. the tangible landscape and the way in which it is organized. This includes the functional uses of space, of infrastructure and of the built environment - elements that shape our spatial experiences (Lefebvre, 1991; Yacobi, 2003b). In order to do so, I will critically analyse the ways in which the Palestinian city of Lydd was transformed into the 'mixed city' of Lod. More specifically, I will present the spatial and demographic survaillance and control in the city since 1948 and will follow the changes in the public discourse that had accompanied them. My main argument is that surveillance and spatial control that took place in the city during the Military Administration period has had a significant influence, and was used as a basis for constant supervision of the Arab inhabitants. In the following paragraphs I will outline briefly the spatio-historical background.

Lod is located at the edge of the coastal plain of Israel, and has developed around a junction of routes leading from west to east (Jaffa-Jerusalem) and from south to north (Egypt-SyriaLebanon). There is extensive historical evidence of commercial activities in this area, and the first railway line to Lod was constructed as early as 1892. The British occupied the city in 1917 and invested widely in development, including the construction of the train station, the renovation and enlargement of the railway tracks and the establishment of an airport. In 1920 Lod was declared the capital of its region. In 1922 the British Mandate Department of Statistics reported 8,103 inhabitants, including 7,166 Muslims, 926 Christians and 11 Jews. In 1944 the Anglo-American 
committee counted 16,780 inhabitants, including 2,000 Christians (Yacobi 2003a; Vacart, 1977).

As with other Palestinian cities and villages, 1948 was a turning point in the history of Lod. The Israeli army occupied the city, which was to be part of an Arab state according to the 1947 UN partition plan. In Operation Dani, initiated by the Israeli army, 250 Palestinians were killed, and about 20,000 inhabitants escaped or were forced by the Israeli army to leave the city. However, the need for specific labor, such as the railway workers in Lod, was the main reason for allowing 1,030 Palestinians to remain in the city (IDF Archive, Military Administration Report, October $10,1948,1860 \backslash 50-31)$.

The establishment of the Israeli state and the 1948 war created a new reality in the city. When Lod was first occupied, the Israeli Military Administration gathered the remaining Palestinians in a surrounded enclosure, marked by a wire fence. This was a first step towards a policy of urban panopticism.

The notion of urban panopticism is derived from the work of Foucault, ${ }^{2}$ who understood space as a crucial element explaining power relations. Furthermore, modern urban space is perceived in Foucault's words as a 'laboratory of power' (Foucault, 1977: 204). In this context Foucault explored the characteristics of panoptic institutions where there was no need for bars, chains and heavy locks:

[A]ll that was needed was that the separations should be clear and the openings well arranged. The heaviness of the old 'houses of security' with their fortresslike architecture, could be replaced by the simple, economic geometry of a house of certainty (Foucault, 1977: 362).

Indeed, such approach is already mentioned in relation to the planning apparatus in Israel. Weizman (2002), for instance, adopts this term in order to describe the form of the Jewish mountain colonies in the West Bank:

[These] settlements are constructed according to a geometric system that unites the effectiveness of sight with spatial order, producing "panoptic fortresses", generating gazes to many different ends. Control - in the overlooking of Arab town and villages; strategy - in the overlooking of main traffic arteries; selfdefence - in the overlooking of the immediate surroundings and approach roads.

\footnotetext{
2 Originally, the panopticon had been developed in 1787 by Jeremy Bentham, and was used as an architectural model for buildings whose essence was social control such as hospitals, prisons, factories and the like. From an architectural point of view the panopticon is composed of two concentric cylinders: the outer is six floors high and faces a central space, in which the smaller cylinder is located; an individual in the central cylinder supervises and visually commands the outer cylinder. The spatial relations between both cylinders and the light settings expose the faces of the supervised and hide the presence of the supervisor. By so doing, one cannot know whether there is a supervisor in the central tower, but it creates the illusion that he is always there.
} 
Settlements could be seen as urban optical devices for surveillance and the exercise of power.

Yet, Foucault himself developed this theme far beyond an analysis of the architectural form. Following this line of thought he described panopticism reflecting and symbolizing the location of bodies in space and the hierarchical organization of power whenever a particular form of behavior is imposed (Foucault, 1977: 364).

Adopting this point of view focuses on panopticism as a form of "political technology". ${ }^{3}$ After 1948, urban panopticism in Lod was used as a means for constant surveillance, through direct and indirect mechanisms of control over the Palestinians that were perceived as enemies (Bashir, 1999; Rouhana and Ghanem, 1999; Bishara, 1993). This policy included transferring hundreds of Palestinian labourers from the Galilee to work in the abandoned vineyards in and around Lod. Those workers lived in the Arab enclave and were not allowed to remain in the city at the end of the agricultural season (Ben-Gurion Archive, 9837-27\8\48; IDF Archive, Military Administration Report, Oct. 10-Nov. 15, 1948, 1860150-31).

The security forces were the main body that coordinated the relations between the Palestinians and the Israeli governors. Archival documents show that these forces had total control over the Palestinians' conduct, including their movements and their right to work (IDF Archive, 1860150$31,1860150-32)$. It is important to note that in order to gain these rights, proper political behavior of the Palestinian individual towards the Israeli governing body was necessary.

This approach was supported by Israeli public discourse that constructed a negative image of the remaining Arabs. Prime Minister Ben-Gurion blamed the Palestinians in Israel for supporting the surrounding Arab countries, and President Ben-Zvi claimed that the Palestinians aimed to complete Hitler's project (Benziman and Mansour, 1992). Nonetheless, the remaining Palestinians in Lod became powerless; their urban culture as well as their collective identity and leadership had been undermined and as reported at the time, they were a fragmented society that could not endanger Jewish hegemony (IDF Archive, Military Administration Report, October $10,1948,1860 \backslash 50-31)$.

In April 1949, the Military Administration regime in Lod ended (IDF Archive, Terminating the Militar Administration in Ramla, Lod and Yaffo, June, 23, 1949, 1860150-31), but there was still wide agreement concerning the necessity of surveilling the Palestinian population in the city. Every aspect of their life was under control. In the first period after the war, Palestinian refugees tried to penetrate and resettle in their vacant houses in Lod. The authority's reaction included military acts against them as well as a massive settlement of Jewish immigrants, mainly Mizrahim (oriental Jews) (IDF Archive, Military Administration Reports, December 23, 1948, Decemeber

\footnotetext{
3 Very often the panopticon in post-modern societies is explained in relation to surveillance technology such as CCTV (Koskela, 2003). Yet, in this paper I refer to it as "political technology" (Foucault in Danahar et al., 2000: Chap.5), i.e., sets of regulations and institutions that shape urban space.
} 
28, 1948 and January 11, 1949, 1860150-31). ${ }^{4}$ In 1949 126,000 (66 percent) of the 190,000 Jewish newcomers who arrived in Israel were settled in abandoned Palestinian houses in the 'mixed'cities, including Lod (Morris, 2000: 263).

However, depite the intensive Judaization process which aimed to control the balance in numbers between the Jews and Palestinians, an ongoing process of internal migration and natural growth affected the ethnic balance. Data drawn from census figures shows that in the last decades the Palestinian population has increased from 9 to over 20 percent, while the Jewish population decreased from 91 to less than 80 percent. ${ }^{5}$ In order to understand these changes, I will now follow the historical events that have undermined the seemingly hermetic process of Judaization.

In addition to the Palestinians who remained in Lod after 1948, waves of Palestinian internal refugees $^{6}$ have settled in the city since the 1950s, recomposing the city's social profile and presenting more complex demographic strata. One of the dominant groups included families from villages in the Sharon region. This group was resettled in Lod as part of an agreement with the Israeli authorities. Their original land had been confiscated and each family was compensated by a new plot, 10 percent in size of its original property. Yet the case of these families is unique, since unlike other Palestinian groups in the city, they owned their land. ${ }^{7}$

During the 1960s, as part of the official Israeli policy, Bedouin families were settled in the northern part of Lod, in the railway district, and integrated into the Jewish economy as cheap labor. The location of Lod, close to the Tel Aviv metropolis, has also attracted other groups of Palestinian internal migrants. Some of them have illegally occupied vacant and often partly demolished houses in the city.

Another group of Palestinians that were resettled by the authorities are the 'collaborators' Palestinians from the Gaza Strip and the West Bank, territories occupied by Israel in 1967. These Palestinians have cooperated with the Israeli security authorities, and are therefore viewed by other Palestinians as traitors. The authorities had to move these families from their original villages and cities, where their lives were endangered, and compensated them with housing in the Wardah quarter that includes 50 housing units built on state land.

This demographic flow embodies political, cultural and economic tensions that are spatially expressed. As shown in figure 1, the city presents a segregated pattern ${ }^{8}$ in which Palestinians dominate two areas in Lod: the western as well as the northern parts. These segregated areas

\footnotetext{
${ }^{4}$ In 1969, for instance, it is reported that Lod's inhabitants were 50 percent Jewish immigrants from North Africa, 18 percent Jews from other Middle Eastern countries, 24 percent Jews from Europe and 8 percent Arabs. See: Hashimshoni, 1969

5 This data is based on the 1995 Census and on Lod's Master Plan information, 1997

6 The number of Palestinian internal refugees now reaches 250,000, while many of them live in unrecognized villages and neighbourhood. For more details see: Palestinian Refugees and the Internally Displaced within Israel Conference, Nazareth, 26.3.2003 (http://www.ac-ap.org)

${ }^{7}$ For more details on this case see: Yacobi, 2002

8 On the nature and dynamics of segregation of mixed cities in Israel see: Falah, 1996 
which are the locus of the Palestinian citizens' daily lives constitute the perceived space. In addition, these zones lack basic infrastructure and a survey of 500 Palestinian households in the city shows that over 30 percent of them are not connected to the sewer system, 49 percent have complained about humidity problems, 43 percent have rainwater leakage, 29 percent have structural problems, 28 percent of the houses are marked for demolition, and 26 percent are used for dwelling although unfinished (Brukdeil's Report, 1997).

These districts are characterized by what has been defined by the authorities as massive illegal construction. According to my findings, around 50 percent of the Palestinian population in the city live in 'illegal' structures, forming the largest informal construction activity within non-Arab cities in Israel.

The percived space of the Palestinian districts became signifiers that shape the image of the Arab population in Lod. The Palestinians in Lod are presented in the media not just as the 'Arab enemy' but as a 'social hazard' and the main source of illegal activities, crime and drug dealing, ${ }^{9}$ as we learn from the municipality report, 'Minorities in Lod form 20 percent of the population, while their involvement in criminal activities in the city reaches 60 percent" (Lod Municipality Report, 2000).

Yet, some clarifications must be made in relation to this statement. First, the report counts illegal construction as the leading criminal act. However, it does not mention that this is a result of the demographic engineering policy, which does not respond to the housing needs of the Palestinian citizens of the city, as noted for example by Maxime Levi, who was the mayor of the city in the past:

In relation to the special demographic characteristics of the city... it is appropriate to consider unconventional solutions, to work towards the dispersal of populations out of the city, and to prevent completely the illegal invasion of inhabitants in the future... The Arab population problem, as aforesaid, is severe and urgent. It demands a comprehensive and immediate solution (Lod Municipality and the Ministry of Housing and Construction, 1987 - emphasis added)

However, the reaction of the Arab population to this attitude does not comply with the policy makers' goals. Rather, they struggle in order to achieve their housing rights as described by a Palestinian interviewee:

I am trapped within two circles of discrimination. The first is the national circle that relates to me as a "problem." The second is the municipal circle, and here the situation is worse since it affects my daily life-discrimination on this level is total and deep. My basic rights are abused, my right for housing, my right to have proper schooling for the children. These services are supplied on the municipal level, and we are struggling to achieve them. My point is that there are

\footnotetext{
${ }^{9}$ On the social construction of the other as a result of segregation see: Sibley, 1995 
no planning initiatives for Arabs in Lod. Maybe it is our luck, since if there was some degree of planning, we would not be able to rise against it, and the authorities could claim that they plan for us...This total withdrawal, this total ignorance of our needs motivates us ( An interview with A.M. November 4, 2000).

Indeed, the policy towards the Palestinian citizens of Lod has not changed over the years. They are still the 'enemies' - subject to social and spatial exclusion.

In the last two decades many Jewish immigrants have arrived in Lod, mainly from the former Soviet Union. They are now 25 percent of the city's population, and form the second generation of 'agents'. In Lod Municipality Report (2000) the demographic characteristics of the city are presented as a fundamental issue, claiming that the relative growth of the Jewish population is based on immigration, while the Arab population increases by natural growth, as noted in an interview with the Lod municipality spokesman, "Thank God! What really saved us demographically was the mass immigration of 15,000-16,000 newcomers who arrived in Lod" (Interview with J. Shetrit, Lod municipality spokesman, October 1, 2000).

Nonetheless, at this point it is important to note that not all new Russian migrants in the city are Jewish. Around 30 percent of the newcomers to Israel in the last wave of immigration have been non-Jewish that were able to settle in Israel by virtue of the Law of Return. ${ }^{10} \mathrm{In}$ this context it is argued that despite the contradiction between the Jewish nature of Israel and the non-Jewish immigrant-agents, this migration serves the goal of demographic engineering and hence the shaping of Israel as a "non-Arab State" (Lustick, 1999). ${ }^{11}$

To sum up this section, I will shortly reffer to the existing body of knowlege that deals with segregation (Boal, 1987; Peach, 1996). I propose that the spatial organization of the city is not an organic or natural process reflecting solely economic differences. Rather it is integrated into unequal urban niches that spatially express power relations. These segregated battlefields are the locations in which struggles for the "right to the city" (Lefebvre, 1996) take place. Hence, understanding the patterns of segregation in housing, social activities and everyday life is tightly linked with the analysis of minority-majority power relations.

Indeed, in this section I have attempted to go beyond the debate of whether segregation is enforced by others or a result of community motivations and interests. Such an analytical dichotomy reduces the complexity of reality, since beyond the fact that segregation is a territorial phenomenon it frames social norms and constructs the image of the 'other'.

In this context the peceived space in Lod cannot be seen as neutral; it systematically disables the social and economic mobilization of the Palestinian citizens of Lod. Because of surveillence, control and ethnic segregation, significant numbers of them are experiencing a social environment

\footnotetext{
10 The Law of Return $(1950,1954$, and 1970) defines the right of the Jewish people to return to Israel.

11 For further discussion concerning the socio-political dynamics in relation to the role of the Russian migrants in the judaization of Lod see: Yacobi and Tzfadia, 2004 
where poverty, crime and unemployment are the norm, where social and physical deterioration and educational failure predominate. The effect of segregation on the Palestinians is structural and not individual. It lies beyond the ability of any individual to create a change in his/her life according to personal motivations or private achievements.

\section{Urban Ic onoclasm}

"...[Lod] has changed from a neglected and undeveloped Arab city into a
city of 16,000 [Jewish] inhabitants... Lod, with its clean streets and
plantings and its organized management... is a living example of the
dynamic power of the Jewish people" (Lod Municipal Report, 1952).

As noted in the previous section, the very tangible urban landscape of Lod reflects the sociopolitical processes in the city. Yet, it is important to note that one of the efficient tools for transforming the Palestinian town into a "Hebraic city"12 is the planning apparatus. This debate, despite its centrality in understanding socio-spatial realtions, is still at the edge of academic interest in Israel. Yet, some researchers propose a critical approach that interlink power relations and space production in Israel. ${ }^{13}$

In the context of this paper I would propose that Lefebvre's notion of the perceived space is important since it relates to the way in which professionals such as planners and architects represent space. This conceptualized space is the result of epistemological processes that cannot be seen as autonomous from the socio-political context (Lefebvre, 1991). ${ }^{14}$ Such perspective is neglected in the critical analysis of Isreali landscape which tend to focus on policy analysis (Yiftachel, 2000; Falah, 2000) and political hermenoitics of architectural forms (Weizman, 2002).

Following this, I will argue that the built environment in Lod cannot be seen as merely a technical device of organizing space. Rather, similar to other cultural representations, it expresses, produces and reproduces power relations. This argument will be followed by a critical discourse analysis $^{15}$ concerning the urban texture since the 1948 war through the masterplans from the 1950's and the 1990's, focussing on the actual changes that have taken place in the built environment as well as on the contents and meanings embodied within the planning discourse. ${ }^{16}$ Exposing the discursive dimension of the professional sphere, I will propose, is a key to understanding the spatial dynamics of a city as well as its ideological agenda, which are often neglected in the literature of ethnic urban relations.

\footnotetext{
12 Lod Municipality Archive

13 See among others: Yiftachel (1992; 1997; 2000); Fenster (1996); Segal and Weizman (2003)

${ }^{14}$ For an interpretation and methodological notes see: Yacobi, 2003a; 2003b

15 From a methodological perspective the interpretations and analyses of the texts and documents in this article are based on vast literature that deals with discourse analysis in general and in relation to the built environment and planning in particular. See: Markus and Cameron, 2002; Fairclough, 1995; Hastings, 1999.

16 The limited scope of this paper will not enable me to discuss the relevance of colonial British town planning in Mandatory Palestine to the Zionist planning post-1948. For details see: Yacobi, 2003c
} 
Transforming the Palestinian city into a 'Hebraic city' began when the Israeli State was established, employing a dual mechanism that expressed both a tangible project of colonization and a symbolic construction of a collective national consciousness based on ethnic belonging (Yiftachel, 1999). I would propose to define the physical act of this process as urban iconoclasm, which was rhetorically presented under a scientific planning approach, rationally and objectively concerned with the 'public interest'. Very often this approach demanded massive destruction of the existing Palestinian built environment, an act that was justified as being part of the functional progress towards modernity.

However, as I will demonstrate, a total replacement of the Arab urban landscape was impossible. This was a result of both political and demographic circumstances discussed in the previous section, as well as from he development of a controversial approach towards the indigenous built environment. This approach will be presented using the orientalist discourse, which opened a new perspective for understanding culture as a product of social dominance (Said, 1978). It shows how the Jewish settler society had constructed its imagined sense of place while deforming the content and meaning of the local vernacular and transferring it into a subject of 'local' and 'authentic' but 'non-Arab' belonging.

Historically, the 1948 war had prevented the realization of the new plan of Mandatory Lydda, designed by the architect Otto Polcheck in the spirit of the garden city. ${ }^{17}$ Polcheck's plan, similar to the preceding plan made by the well-known architect Clifford Holliday, ${ }^{18}$ had emphasized the presevation of the ancient core of the city and the construction of its new parts alongside the historical part.

While the expulsion of most of the Arab population and the concentration of the remaining Arabs in separated areas took place, massive acts of demolition of the built area were carried out by the Israeli army. This often occurred under direct governmental commands, and sometimes as a result of an army initiative. However, total demolition of the Palestinian city was not realistic. The flow of Jewish immigrants demanded a housing stock, and the intentions of some Palestinian refugees to penetrate back to their homes required an active reaction in the form of settling the Jewish newcommers in those houses as defenders of the frontiers.

Similar to other frontier settings, the Judaization of Lod was a high priority national project. In 1950 only 9 percent of the city's 12,100 inhabitants were Palestinians, while the rest were Jewish:

The composition [of the Jewish inhabitants of Lod] is diverse and characterizes the kibbutz galuiot ${ }^{19}$ : the origin of 50 percent is from Poland, Romania and Bulgaria and the origin of the other 50 percent is Morocco, Tunisia, Turkey and

\footnotetext{
17 Otto Polcheck is a Jewish architect who migrated to Palestine from Czechoslovakia after studying in the Bauhaus. For more details see: Yacobi, 2003c

18 Clifford Holliday was a well-known British architect and town planners, who had lived and work in Palestine during the Mandate period. For more details see: Yacobi, 2003c

${ }^{19}$ Kibbutz Galuiot is an essential concept in Zionist discourse. Its meaning is the melting pot of diasporic Jewish immigrants from different countries of origin.
} 
Iraq. However, seven years after it has been established as an independent Hebraic city, it is still far from being an integrated urban entity that has taken off its diasporic dress. The different [Jewish] communities preserve their customs and manners, a fact that prevents healthy and desirable development (Galili, "Al Hamishmar" newspaper, May 17, 1954).

This critic cited here explores an essential stratum within Zionist discourse, which aims to create a modern and aggregated society in an old-new space - the 'Hebraic city'.

Furthermore, it uses the remaining indigenous architecture as a symbol not only of the intimidating enemy landscape, but also of the diasporic Mizrahi origins of the Jewish migrants:

While one walks in the Sakna ghetto and watches the degenerated life style of its inhabitants, who live in dark houses and cellars without basic sanitation... one has the feeling that nothing had changed in the life of these people that were transferred from the dark known ghettoes of Morocco (Galili, "Al Hamishmar" newspaper, May 17, 1954).

Paradoxically, the 'agents' - mainly the oriental Jews that were implementing the project of Judaization - were being marked as the cause for the backwardness of the city. The migration policy of the Israeli authorities had brought together into the city many welfare and social problems, as defined by Zvi Itzkovitch, the mayor of Lod twenty years later:

Everyone [of the Jewish migrants] occupies a house from the abandoned property... Instead of searching for solutions to rehabilitate the Arab city that was neglected, such as erecting new factories, the Sochnut [the Jewish Agency] and the government compress in the city welfare cases from the entire country (Lod Municipality Archive, 1972).

What urban landscape should be created in the city of Lod in order to replace the Arab, diasporic and backward built environment? The response for this question was clear at the time, and it had to do with the project of modernization that represented the ideological denial of the oriental past and present. In a deterministic way the Israeli public discourse tied the characteristics of the "dark ghetto" to social maladies that could be healed if the physical conditions would improve:

...[T]hose who live in the new housing blocks will not live peacefully with the ghetto inhabitants... Let's realize the experts' and engineers' decision concerning the necessity to demolish all this area in order to clean the social dirt (Galili, "Al Hamishmar" newspaper, May 17, 1954).

The "housing blocks" mentioned above were an outcome of the first Israeli master plan initiated in 1954 and approved in 1958 (see figure 2). The architect, Michael Barr, had advocated modernistic planning principles. The new urban scheme is based on a modernistic planning approach and its zoning, public open spaces and efficient transportation system demonstrate 
total estrangement to the existing Arab landscape, 'It is necessary to prepare a detailed urban scheme without any relation to the existing buildings" (Lod Municipality, 1952).

Barr's modernistic paradigm was compatible with the ideology of the Jewish settler society. While Polchek's and Holliday's orientalist views advocated the reconstruction of the old city of Lydda, Barr's ambition was to transform Lod's Arab urban fabric in the name of modernization:

We should gradually transfer the inhabitants of the ruins [the old city] to new housing zones. The vacant area we should use partly for new planned housing districts and mostly for the construction of public buildings and public open spaces for the needs of the population that lives around it (Lod Municipality Archive, 1972).

In this context I will mention Sandercock's claim that modernist planners were the "thieves of memory". They have been "embracing the ideology of development as progress" and by doing so they "have killed whole communities, by evicting them, demolishing their houses" (Sandercock 1998: 208). In the case of Lod this argument is valid, though a focus on the project of modernization would be partial, since modernization is not an independent concept; most certainly, it is strongly tied with other ideologies. As illustrated above, similar to other colonial practices, the act of planning was justified as being more civilized than the indigenous population's use of space (King, 1990).

Urban iconoclasm was not presented as an act of aggression, but as an act towards modernization. Hence, the modernist interpretation of the city and its inhabitants was used as a moral and ethical foundation to make them subject to surveillance and control. For without constructing the 'other' as a less civilized enemy, there would have been no justification to control them. This approach had characterized the first decade of the establishment of Israeli Lod, and was again repeated 20 years later:

We have received the city abandoned, underdeveloped and dirty, with no electricity, sewerage system and running water, roads and sidewalks. The streets, especially the main street, were miserable alleys. In order to build a city, excellent city-builders are necessary. In order to rehabilitate an underdeveloped city there is a need for good will, energy, initiative and above all - money... Roads and sidewalks were paved all over the city, neglected places became well-groomed, deteriorated squares are flowering (Zvi Itzkovitch, Lod's mayor. Lod Municipality Archive, 1972).

This citation presents the overlapping mechanisms that have produced Lod's urban landscape; a modernist approach to hygiene and planning, and a concept of Jewish ethnicity that had replaced filth and backwardness.

Barr's urban scheme took into account that some of the religious buildings in the ancient part of the city will remain. However, their original function, that used to be part of the communal Palestinian city life, was no longer valid in the planner's eyes. Here, urban design had a special 
role in confining space and memory into the limitations of the hegemonic Jewish, western and modern frameworks:

The religious institutions and the special buildings will remain within the [new planned] parks, and if they will be vacant we will use them for museums and exhibitions as well as an artists' hostel where artists will find the special atmosphere inspiring for their creations. We might consider as a memory of the past the preservation of some alleys that are characterized by special buildings (Lod Municipality, 1952).

Until the beginning of the 1970's most of the Arab city had been demolished, leaving a void named "Park Ha-Shalom", the Hebrew name for Peace Park. The planners followed their ideological commitment of healing the oriental space. Indeed, urban iconoclasm was used both as a means and as an end in itself. In the name of modernization and newness, it had enabled the physical colonization of Lod, while symbolically transforming Lod's sense of place.

While Lod underwent massive urban transformations, new voices began to be heard; voices that called for preserving Lod's architectural heritage. The local municipality organized a conference about this issue in 1992 where this apparent shift towards the historical importance of remnants was expressed:

The participants of the conference expressed their impressions by stating that the historical sites in Lod are more beautiful than those they had visited abroad" ("Moked" - local newspaper, October 30, 1992).

Preserving Lod's indigenous built environment was seen, first and foremost, as a source for tourist attractions. This approach was mentioned before by planner Michael Barr and was repeated in this conference forty years later, “...[W]e could restore this area, and it can easily compete with old Jaffa: with museums, galleries, tourist shops and art centers" ("Alternativa" local newspaper, October 9, 1992).

However, in relation to the apparent shift towards the Arab landscape of Lod, I would propose that its commercialization must be viewed within the context of the architectural discourse in Israel during the 1960's, that was dominated by a yearning to define 'deep-rootednness' and a local national regionalism. This was a dialectical process that had adopted the indigenous landscape as an object of inspiration on one hand, and had excluded the 'intimidating other' on the other.

This apparent shift towards preserving the Arab urban texture is but another form of dominance. Behind it lie the domestication of landscape, time and space as means for constructing the collective sense of 'primordial' belonging, referring back to an 'authentic being', as I will present in the following papragraphs.

In 1990 Sa'adia Mandel, one of the leading architects in urban conservation in Israel, was hired by the Israeli Committee of Site Preservation to prepare a Conservation Master Plan for Lod. 
Based on his proved proficiency in transfering old Jaffa into a judaized picturesque artists colony, the main focus of his new plan was to highlight Lod's potential for tourism:

The municipality of Lod aims to return the city to the route of tourism, and to present to visitors from Israel and abroad the historical sites of the city. These sites demand rehabilitation that will rediscover and transform them into attractive touristic sites (Preservation Master Plan, 1991).

However, this task required a re-reading of the city's history and a reshaping of memory as noted by the architect himself:

...[A]t the end of the process I had reached some conclusions... I told Maxim Levi, the mayor, that this was a conservation and tourism as well as an educational project. There are people in Lod aged 50, and they have the right to know whether Lod was occupied or liberated... I am not using such words "occupation" and "liberation" fortuitously. In this story I have a clear position. I know that Emek Izrael was occupied. The Zionists bought the land there from the Arab landowners and settled there - this is an elegant occupation if you want, I am not saying that it was fair, but elegant is the most innocent term I can use. Then, the war of liberation broke out and Lod was occupied - this was less elegant.... My thesis is that in Lod there is space for both them and us ( Interview with Sa'adia Mandel, September 20, 2000).

Mandel's work was published in a detailed report presenting the history of the city chronologically, and showing each period and its central monuments that should be preserved. It is a voyage in time that goes back to the Neolithic and Iron ages, the Roman, Byzantine and Early Arab periods, the Crusader, Mamluk, Ottoman and British Mandate times, and finally the period from 1948 up to the present.

This document describes the characteristics and monuments of each period, though its subtext deals with a reconstruction of the historical narrative of the city. Two significant examples illustrate this. While describing the transition from the Byzantine period to the Early Arab period, the text mentions the process of urban iconoclasm that had characterized the Muslim occupation stating that the city "was demolished by Muslims, and the stones were taken for the construction of the city of Ramla". However, while relating to the period from 1948 onwards, the almost total destruction of Lydda is ignored, and "rational" circumstances explain its Judaization after the "liberation" of the city was completed:

On July $11^{\text {th }} 1948$ Lod was occupied by the Israeli Defense Army as part of "Operation Dani". Its Hebraic name - Lod - was restored. New home-comers populated the abandoned dwellings, thus using efficiently the existing stock of housing

Obviously, the efforts to 'domesticate' the city's memory and monuments serve the construction of an Israeli collective identity framed by the Zionist narrative, claiming that the Jewish people 
have returned to 'a land without people' waiting for 'a people without land'. However, since Lod is a 'mixed city' composed of both Jewish and Arab citizens, relying on the concept of terra nullius is problematic; despite its iconoclastic past the city still contains both Arab architectural characteristics and an Arab population. Mandel is conscious of this and though he declares his commitment to Zionism, he tries to give a wider meaning to the Master Plan:

When I mentioned the oil-press building of the Hassona family ${ }^{20}$ I was asked to hush this matter up. I said that I want the Hassona family to operate their ancient oil-press. There is no reason why they shouldn't... Every Arab building we found had been destroyed, the Jews have deceived themselves - we thought that we could erase... but everything is still alive and I have tried to express this in the Master Plan (Interview with Sa'adia Mandel, September 20, 2000).

However, as Rabinovitz (1993) noted, any reference to the non-Jewish legacy and cultural heritage are conceived as problematic for the Jewish majority, for recognizing the 'other past' may expose the competitive identity to the Zionist one. Indeed, Mandel's plan has never been realized, and the Arab remains in the city were left to disappear 'naturally'.

One of the only projects that were realized in preserving Lod's urban fabric is the conservation of an Arab building in the city center. This building was renovated in order to serve as the offices of the mayor of Lod. Until then a modernist building housed the offices as well as the representative functions of the municipality. Nevertheless, the apparent shift towards the Arab landscape was translated into a symbolic transfer of the city leaders into an ancient house, situated at the end of a visual axis. The house, which was once part of an urban texture, had become a displaced 'monument'(see figure 3). Its typical symmetry, the hierarchical movement in space from private to public as well as its ceremonial entrance have been deformed. A decorated sign quoting a verse from Jeremiah greets those who approach the building: "Children come again to border" (Jeremiah 31:17).

Who are the children to come again to border? It seems that the offices of Lod's mayor come within an approach discussed by the orientalist discourse in relation to the international exhibitions (Mitchell, 1998; Crinson, 1999). In these displays the artificial objects were supposed to create an impression of order, authenticity and scientific chronology; this in turn suggested a certain organization of knowledge. In the Conservation Master Plan Lod's 'historical collection' suggested by the architect was a succession of anecdotes, organized so as to present contemporary reality as a linear and natural continuation of the past. This point, in the context of Lod that was formerly a Palestinian city, is very central for understanding the reconstruction of the historical narrative that presents a linear historical continuity of Jewish settlement in the city, as stated by the Mayor at the time of preparing the plan, "During hundreds of years, in different epoques since the Canaanite period... Lod was the only place in the world in which a Hebraic settlement existed" (Preservation Master Plan, 1991).

\footnotetext{
${ }^{20}$ The Hassona Palestinian family remained in Lod after the 1948 war, and they still own the ancient oilpress building
} 
To sum up this section which dealt with the perceived space and its contribution to the production of urban lansdcape, I will point out that the very act of planning, discursivelly and practically, has a significant role in 'rationalizing' power relations. Indeed, the production of urban space is an ongoing process that involves hegemonic ideology and socio-political relations, while in the case of Lod these are based on two interrelated processes; Judaization on one hand and de-Arabization on the other. This requires 'scientific' disciplines to contribute to what has been defined by Said as a "struggle over geography". This struggle, as noted by Said, is complex as "it is not only about soldiers and cannons, but also about ideas, about forms, about images and imaginings" (Said, 1993: 6).

In this context the contribution of the spatial practices such as architecture, urban design and planning is significant; on one hand they codify within their professional discourse the ideologies they serve, while on the other they transform the built environment, urban form and space. Their power, indeed, is in their 'unquestionable' effect of surveilling daily experience and accumulating meaning, which can then be decoded through analyzing the discourses in which they are produced.

Finally, the planning processes in Lod are indeed visible, though not exactlly in the ways the planners had intended. Realizing the vision of a modernistic space that welcomes the newcommers was impossible in the first years, mainly since the Palestinian housing stock was used to house the Jewish migrants. Yet, as figure 4 demonstrates, inspite of the destruction of the indigineous landscape, the massive informal construction of the Palestinian neighbourhoods in Lod contradicts the utopian urban landscape, and signifies vast areas in the city as Arab, as noted in a popular Russian migrants newspaper:

...[S]ometime ago the Arabs have constructed a big house on a plot that the municipality had devoted for establishing a national park in which archeologists had found the remains of an ancient Jewish wine-press... But instead of a national park an Arab house is constructed and beside it a horse and sheep pen. Instead of tourists and inhabitants, only sheep and horses are visiting here, and the neighbourhood [Jewish] inhabitants hear the animal's noise during the night and smell the "pleasant" odor" ("Vesti" Newspaper, May 9, 2002 - originally in Russian).

\section{Urban (Counter) Narrative}

As discussed in the previous sections, the urban landscape in Lod has been shaped through the years by the ethnocratic regime ${ }^{21}$ through 'top-down' planning policies. This was followed by

\footnotetext{
${ }^{21}$ Ethnocracy is a distinct regime type established to enhance the expansion and control of a dominant ethno-nation in multi-ethnic territories. In such regimes, ethnicity, and not citizenship, form the main criteria for distributing power and resources. As a result, they typically display high levels of uneven ethnic segregation, and a process of polarizing ethnic politics (Yiftachel 1999; Yiftachel and Kedar, 2000). Urban ethnocracy critically analyses a situation inwhich a dominant group appropriates the city apparatus to buttress its domination and expansion. In such settings, conspicuous tensions accompany the interaction
} 
'bottom-up' initiatives of massive unauthorised construction of housing and services by the Arab community in the city. As I will outline in this section, this spatio-political tension is in the core of the construction of meaning as well as of a sense of belonging and identity within the Palestinian population. This claim will be articulated within the analysis of the lived space that embodies images, symbols and associative ideas of the 'users' that give meaning to space.

In this section I have selected one in-depth interview conducted with Hannan, an Arab inhabitant in her mid 40's, who lives in a well-serviced middle-class "Jewish Neighbourhood". 22 The main question to be looked through this narrative is in what ways do the processes explored in this paper effect the construction of identities of those inhabitants that are not included within the hegemonic group, and how do these identities - in turn - shape symbolically urban space. Yet, I would like to stress that my intention is not to claim that my interpretations are undoubtful representations of reality. Rather, I would suggest that the lived space as reflected in Hannan's narrative is an added dimension that challenges and critically examines the 'objective' facts.

Despite my request from Hannan to describe her everyday life in Lod, she preferred to open the interview with one of the central themes around which her narrative was constructed; the house. The first section of the interview is devoted to this theme and she started by saying: "[I]n Lod this is our third house". Indeed, many researchers have pointed on the importance of the domestic space as the extension of the self (Carsten and Hugh Jones, 1995), as well as a fundamental source of shaping identity (Cohen, 1982; Yacobi, 1997). Yet, I would suggest that in Hannan's narrative the private house also embodies a symbolic meaning that functions as the 'container' of the Palestinian collective narrative, as the following example demonstrates:

...From the first house that belonged to my grandfather, we had five houses according to the number of brothers in the family... The second house we lived in, used to be the property of a Palestinian family that was expelled to Jordan in 1948 and that came to visit their house while we lived there

Indeed, Hannan is counting the houses to which her family had moved, while mentioning the fact that the "second house" had belonged to Palestinian refugees. Furthermore, counting the different houses is a pattern that also serves the collective politization of her narrative, stressing the fact that it is a continious process, forced by the existing power relations in the city. It was the deterioration of the Arab neighbourhoods in Lod which had obliges her family to move into another district:

...So we said, its about time to depart, we were looking where to depart, yes we were looking where to depart

between the city's economic and ethno-territorial logics, producing sites of conflict and instability, and essentializing group identities and ethnic geographies. For further analysis see: Yiftachel and Yacobi (2003; 2004).

22 This interview will be examined using a method of 'spatial narrative analysis', a methodology developed in Yacobi, 2003a. It is important to note that because of the limited length of this paper, I will be able to present here only certain parts of this interview. 
Repeating the verb "to depart"23 relates to Hannan's mind-set of living in closure that is shown again when she refers to her present house and neighbourhood:

...Here everyone is locked in his own house... there are isolated houses, organized in straight lines... I hate to get out, whenever I leave the house $I$ have a war, I have a war

This negative image was unexpected, since Hannan's family lives in one of the best quarters of Lod, though they are the only Arab family there. The very spatial metaphors of "straight lines" and "isolated houses" were presented during the interview as the opposite of her childhood housing environment that was dominated by Palestinian inhabitants:

....A lot of houses, a lot of trees and a lot of kids playing. The houses are ordered in circles and all the people are going out, gathering, laughing, a lot of joy... old women watching through the windows

Here the image of "circles" has nothing to do with the physical reality of her past neighborhood. Rather, it is a way of symbolizing the communal collective feelings which also mentioned by using plural nouns (a lot of houses, trees etc.) and positive connotations ("joy","gathering"' etc.).

This narrative presents a nostalgic perspective towards Hannan's past. But here again, this involves not solely the personal memories but the collective Palestinian sentiments to the city as noted by her:

50 years ago [Palestinian] cities in this area were really something important, respected and known; intellectuals' cities. But they destroyed the city, they simply destroyed it. Lod has a name of a city but from a cultural point of view it is not a city anymore, it is just a dump

As can be interpreted, the loss of the glorious past and the negative present image of urban space which is "just a dump", is highly politicized by accentuating that "they" - i.e. the Israelis have "destroyed" the city. Additionally, during the interview she criticizes the authorities' planning policy, mentioning the "dark side of planning" (Yiftachel, 1998), which aims to control and ghettoise the Arab population:

The new housing project was designed as a trap, no one wanted to move there.

Do you know these drawings of rattraps? That's how it is

Indeed, in Hannan's narrative the spatial and demographic dynamics presented in this paper come up when she uses another metaphor that signifies the 'dirt':

23 "Latzet" in Hebrew 
...Gradually the Jews left the area, their old houses were demolished by the authorities and the developers. Only the Arabs were left to live there and the neighbourhoods became like a garbage pile

Beyond this description lies one of the most significant themes in this narrative, which is the symbolic reversibility of power relations. While Israeli public discourse focuses on the Arabs as the main reason for the deterioration of the city, Hannan repeats more than once that the Jewish inhabitants are its cause, expressing a sense of belonging and reconstructing facts through 'othering':

...Who are the real Lodians? The Jews had come to the entire country, ok [laughing] but why did they send all the weak Jewish migrants to Lod? They did not contribute anything, they are the reason for the city's deterioration.

This claim is further epitomized when Hannan symbolically reverses 'common knowledge' concerning who's city is Lod:

The Jews leave the city, they leave the city, they leave the city. ...There is no sense of belonging in the Jewish side. From the Arab side there is, I suppose, a sense of belonging. I, for instance, have enough money to buy a house somewhere else, but this is my city, ok?

Hannan uses her sense of belonging as a counter narrative to the 'top-down' policies, though the following anecdote proves that her ability "to buy a house somewhere else" is not an easy task in a city which is based on ethnic segregation:

...I have an anecdote. When we came to buy this house we were standing outside and talking to the previous owner of this house. Suddenly she said: 'lower your voice! so the people here will not recognize you, although you are Christian. So I said: you can tell them all loudly that I am doing them a favour by agreeing to live here.

To sum up this section, I would like to quote Hannan in relation to her identity of resistance, which is also a counter product of the ongoing ethno-national conflict. In addition to her urban sense of belonging and in reference to the wider Israeli-Palestinian conflict she indicates an imagined space linked to her national identity:

The establishment refuses to accept our right to be Palestinians just because of the fact that we [the Palestinians citizens of Israel] are here and they [Palestinians in the Palestinian Authority] are there, just because of the circumstances by which we are stuck here and they are stuck in a different region, and the establishment does not accept our identification with our Palestinian brothers and sisters. What does it means to identify with them? It is not an issue of identifying. They are us. We are they. 


\section{Discussion}

The multiple processes that have taken place in Lod's urban space were not evolutional or natural. Rather they are products of the Israeli ethnocratic project and its purposeful actions which express the the role of ideology in the production of residential segregation and informal urban spaces in Israel. This approach is common to settler societies where conflict with the indigenous population plays a central role in the formation of national collective consciousness (Yiftachel and Yacobi, 2003; 2004).

The 'mixed' urban context in Israel presents a 'double trap' for the Palestinian citizens; in a state that defines itself as a Jewish state and thus allocates resources according to ethnic hierarchy. They are further discriminated in a city that declares itself to be 'mixed' but excludes its Arab inhabitants, their planning needs and their identity. This logic determines the city's planning policy, the flow of capital as well as the cultural production anf the use of modes of surveillance for demographic and urban panopticism.

As I have demonstrated in this article panopticism cannot be understood and analysed only through the architectural dimension of space or trough the interpretation of the form, as noted by Foucualt himself (1982: 376-377):

...[A]rchitecture... is only taken as an element of support, to ensure a certain allocation of people in space... as well as the coding of their reciprocal relations. So it is not only considered as an element in space, but is especially thought of as a plunge into a field of social relations...

Here stands the theoretical link to Lefebvre's notion of space. Lefebvrian understanding of the simultaniously production of space (i.e the conceived, perceived and lived) paves the road for a new understanding of power relations and their effect on space production. Furthermore, this attitude also gives attention to the "bottom-up" counter products and their potential effect in transforming reality. And indeed, hegemonic oppression calls for a reaction, which comes in the form of initiatives by the Palestinian inhabitants of Lod in order to achieve their right to the city. As noted by Koskela (2003: 306):

control is never completely hegemonic. There is always an element of resistance. Surveillence can be turned to 'counter surveillence', to a weapon for thiose who are opressed.

Indeed, the conceptualization and the role of spatial protest as an alternative pattern of social opposition is important. Spatial protest as I will conclude is characterized by the formation of autonomous acts reflecting personal and social needs that often contradict the interests of those in power. These acts are based on existing social networks and despite their informality they identify the limits of the state's control which requires to compliance with a dictated social order. 
Moreover, this pattern of objection, despite its arbitrariness, produces social and political conciousness and thus has a subversive potential. ${ }^{24}$

The perceived space clearly reflects the Arab inhabitants' spatial protest. Unauthorized housing construction results from the very basic need of supplying shelter, yet its visibility and scope as well as the inability of the authorities to put an end to it point on its strength. Simultaneouslly, the image of the "Arab enemy" as constructed with the establishment of Israeli Lod in 1948, was transformed into a 'social problem' attached to the discourse of 'llegality' that 'endangers' the image of the city.

This leads us to the symbolic dimension of the perceived space that threatens the cultural existance of the city as well as the planners' and policy-makers' achievements. In the face of the efforts and resources that have been invested in order to reshape the built landscape of Lod, it is gradually transforming again into an 'Arab cityscape' in its architectonic image as a result of the extensive uncontrolled informal construction. I assume that this form of spatial protest is not necessarily a conscious act, but the signification of wide districts in the city as 'Arab' results from theses visible acts of construction. Referring to this, I will also note that the spatial protest in relation to the conceived space is significant.

Spatial protest clearly appears in the analysis of Hannan's lived space. The personal as well as the collective meaning of urban space appear to be a direct result of 'one-way' power relations. Yet, a careful analysis of the interview with Hannan shows that there are counter narratives of resistance, that exposes a sense of communal place and belonging to the city, represented symbolically in a strategic reversal of power relations.

Finally, as this article shows, the production of urban space in the Jewish-Arab mixed city of Lod, cannot be understood solely in the dichotomic analysis of top-down processes and policies. Rather, a deeper understanding necessiate acknowledging the bottom-up initiatives and their role, as noted by Lefebvre:

...[W]e can see how a counter-space can insert itself into spatial reality: against the Eye ansd the Gaze, against quantity and homogeneity, against power and the arrogance of power... (Lefebvre, 1991: 382).

\section{References}

Bashir, N. (1999) The Palestinian Inhabitants in the Mixed Cities - Demography, Education Employment and Crime. The Center of Alternative Information. (Hebrew)

Benziman, U. and Mansour, A. (1992) Subtenants. Keter, Jerusalem. (Hebrew)

Bishara, A. (1993) On the Question of the Palestinian Minority in Israel, Theory and Criticisms, 3: 7-35 (Hebrew)

${ }^{24}$ On similar patterns of 'bottom-up' resistance see: Holston, 1989; Kemp, 2002 
Boal, F. W. (1987) Segregation. In: Pacione, M., (ed.), Social Geography: Progress and Prospect, London: Croom Helm, 90-128

Brukdeil's Census of the Arab Families in Lod (1997). (Hebrew, not Published).

Carsten, J. and Hugh-Jones S. (1995) Introduction. In: Carsten, J., and Hugh-Jones S., (eds.), About the House: Levi-Strauss and Beyond, Cambridge University Press, 1-46.

Central Bureau of Statistics (1995) The Geographical-Statistical Vision of Urban Localities in Israel, 6,C. (Hebrew)

Central Bureau of Statistics (1999) Statistical Abstract of Israel, 50. (Hebrew)

Cohen, A. P. (1982) Belonging: the experience of culture. In: Cohen, A. P., (ed.) Belonging: Identity and Social Organisation in British Rural Cultures, Manchester University Press, p.p.: 1-18.

Crinson, M. (1996) Empire Building: Orientalism and Victorian Architecture, Routledge, London and New York.

Danahar, G., Schirato, T. and Webb, J. (2000) Understanding Foucault. London: Sage.

Fairclough, N. (1995) Media Discourse. Edward Arnold, London.

Falah, G. (1996) Living Together Apart: Residential Segregation in Mixed Arab-Jewish Cities in Israel. Urban Studies, 33(6): 823-857

Falah, R. (2000) Welfare Geography of a Peripheralized National Minority: The Case of Israel's Arab Population. Urban Geography, 20(5): 417-437.

Fenster, T. (1996) Ethnicity and Citizen Identity in Planning and Development for Minority Groups. Political Geography. 15(5): 405-418.

Foucault, M. (1977) Discipline and Punish, London: Penguin, trans. Alan Sheridan.

Foucault, M. (1982) [1997] Space, Knowledge, Power. Interview with Paul Rabinow. In: Leach, N. (ed.) Rethinking Architecture: A Reader in Cultural Theory. London and New York: Routledge, 367-380.

Gordon, C. (1991) Governmental Rationality: An Introduction. In: G. Burchell, C. Gordon and P. Miller (eds.) The Foucault Effect. The University of Chicago Press, 1-52.

Hashimshoni, Z. (1969) Lod: The Old City Census. The Evacuation and Construction Authority. (Hebrew)

Hastings, A. (1999) Discourse and Urban Change: Introduction to the Special Issue, Urban Studies, $36(1)$ : 7 12

Holston, J. (1989) The Modernist City: An Anthropological Critique of Brasilia. Chicago and London: The University of Chicago Press.

Kemp, A. (2002) 'Sojourning People' or the 'Big Fire': State Power and Everyday Resistance in the Israeli Frontier. In Hever H., Y. Shenhav \& P. Motzafi-Haller (eds.) Mizrahim in Israel: A Critical Observation into Israel's Ethnicity, 36-67 (Hebrew).

King, D. A. (1990) Urbanism, Colonialism and the World Economy: Cultural and Spatial Foundations of the World Urban System, Routledge, London and New York.

Koskela, H., (2003). 'Cam Era' - the Contemporary Urban Panopticon. Surveillance and Society 1(3): 291-213. http://www.surveillance-and-society.org 
Lefebvre, H. (1991) The Production of Space, Oxford, Blackwell.

Lefebvre, H. (1996) Writings on Cities, London, Blackwell.

Lod Municipality (1991) Preservation Master Plan (Hebrew).

Lod Municipality Report (1952) Lod: Three Years of Municipal Regime. (Hebrew).

Lod Municipality Report (2000) (Hebrew)

Lustick, I. (1999) Israel As A Non-Arab State: The Political Implications of Mass Immigration of Non-Jews. Middle East Journal, 53(3): 416-433.

Markus, T., and Cameron, D. (2002) The Words between the Spaces: Buildings and Language. Routledge. London and New York.

Mitchell, T. (1998) Colonising Egypt, Cambridge University Press.

Morris, B. (2000) The Birth of the Palestinian Refugee Problem, 1947-1949, Am Oved, Tel Aviv (Hebrew).

Peach, C. (1996) The Meaning of Segregation. Planning Practice and Research, 11(2): 137-150.

Rabinivitch, D. (1993) Oriental Nostalgia: How the Palestinians Became Israeli-Arabs. In: Theory and Criticism 4: 141-151(Hebrew).

Rouhana, N. and Ghanem, A. (1999) The Democratization of a Traditional Minority in an Ethnic Democracy". In: Pappe, I., (ed.), The Israe NPalestine Question, Routledge, London and New York.

Said, E. (1978) Orientalism: Western Conceptions of the Orient, London: Penguin Books.

Said, E., (1993) Culture and Imperialism, London: Vintage.

Segal, R., and Weizman, E. (2003) Introduction. In: Segal, R., and Weizman, E. (eds.), A Civilian Occupation. Verso-Babael: 19-26.

Sandercock, L. (1998) Towards Cosmopolis, Wiley.

Sibley D., (1995) Geographies of Exclusion - Society and Difference in the West, London and New York: Routledge.

Vacart, O., (1977) Lod - A Geographical History, Chericover, Lod. (Hebrew).

Weizman, E. (2002) The Politics of Verticality, http://www.opendemocracy.net/debates/article-2-45-804.jsp

Wood, D., (2003) Foucault and Panopticism Revisted, Surveillance and Society 1(3): 234-239. http://www.surveillance-and-society.org/articles1(3)/editorial.pdf

Yacobi, H. (1997) Cultural Needs and Housing Environment, Alef-Beit, the Department of Architecture, Bezalel Academy, Jerusalem.

Yacobi, H., (2003a) Urban Ethnoceacy: the Construction of A City and Identities. PhD Thesis, Ben Gurion Universit. (Hebrew).

Yacobi, H., (2003b) Everyday Life in Lod: On Pwer, Identity, and Spatial Protest in a Mixed City. Jaama 10: 69-110 (Hebrew).

Yacobi, H., (2003c) The Architecture of Ethnic Logic: Exploring the Meaning of the Built Environment in the 
"Mixed" City of Lod - Israel. Geografiska Annaler, 84 (B): 171-187.

Yiftachel, O. (1998) 'Planning and Social Control: Exploring the Dark Side', Journal of Planning Literature, 12(4): 395-406.

Yiftachel, O. (1999) 'Ethnocracy': The Politics of Judaizing IsraellPalestine. Constellations, 6(3): 364-391.

Yiftachel, O., and Kedar, S. (2000) Landed Power: The Making of the Israeli Land Regime, Theory and Criticisms 16: 67-100 (Hebrew).

Yiftachel, O., and Yacobi, H. (2003) Control, Resistance and Informality: Urban Ethnocracy in Beer Sheva, Israel. In: Roy, A., and Alsayyad, N., (eds.) Urban Informality. Lexington Books, 209-239.

Yiftachel, O., and Yacobi, H. (2004). Urban Ethnocracy: Ethnicization and the Production of Space in an Israeli Mixed City. Environment and Planning D: Society and Space 21(6): 673 - 693. 